\title{
POTENSI PAJAK DAN RETRIBUSI DAERAH DI KABUPATEN YAHUKIMO
}

\author{
Agustinus Nusa ${ }^{1}$ \\ jurnalmkd@gmail.com \\ Syaikhul Falah ${ }^{2}$ \\ sehufalah@gmail.com \\ Ivanna K Wamafma ${ }^{3}$ \\ wamafmaivana@gmail.com
}

\begin{abstract}
This research aims to understand how large potential taxes and retribution at the Yahukimo regency. This research using the five taxes and retribution benchmark, namely the growth, economy efficiency, justice, ability to carry out, and conformity as income. By measuring the variables of the potential or not potential in accordance with the specified criteria. The result showed the that variables of economy efficiency, justice, and conformity as income are consistent the taxes and retribution potential in Yahukimo regency. On the variable of economy efficiency concluded that tax charges relatively small, while the threat to the entrepreneurs is the uncertainty neighborhood caused the price increases. Variable of justice concluded that taxes has done in a fair and appropriate with area and the owners capital. Variable of conformity as income is to compare regional regulations with Taxes and Retribution Law, so the results obtained that taxes has in accordance with the rules. While the Growth and the ability to carry out have varying results, taxes and retribution that is quite potentially, potentially or not potentially.
\end{abstract}

Keyword: Growth, economy efficiency, justice, ability to carry out, conformity as income

\section{PENDAHULUAN}

Dalam pelaksanaan otonomi daerah, dituntut kemandirian pemerintah daerah untuk dapat melaksanakan kebijakan desentralisasi fiskal secara lebih bertanggung jawab. Oleh karena itu, pajak dan retribusi yang telah diserahkan menjadi urusan pemerintah daerah sebagai bagian dari kebijakan desentralisasi fiskal baik provinsi maupun kabupaten/kota harus dikelola dan ditingkatkan sebagaia salah satu sumber pendapatan daerah. Hal ini mengingatkan pajak dan retribusi merupakan pendapatan asli daerah dan menjadi sumber pendapatan asli daerah dan menjadi sumber pendanaan bagi keberlangsungan pembangunan daerah dalam kerangka otonomi daerah.

Dalam pelaksanaan pemungutan pajak dan retribusi masih dihadapkan pada persoalan kesadaran wajib pajak yang relatif masih rendah sehingga memerlukan peran dan upaya aparat pemungut pajak, khususnya pada proses pemeriksaan

\footnotetext{
${ }^{1}$ Alumni Mahasiswa Magister Keuangan Daerah Universitas Cenderawasih

2 Staf Dosen Jurusan IImu Ekonomi Fakultas Ekonomi dan Bisnis Universitas Cenderawasih

${ }^{3}$ Staf Dosen Jurusan IImu Ekonomi Fakultas Ekonomi dan Bisnis Universitas Cenderawasih
} 
dan penagihan pajak untuk jenis pajak yang dibayar sendiri oleh wajib pajak maupun jenis pajak yang dipungut berdasarkan penetapan kepala daerah.

Untuk menindaklanjuti terselenggaranya, peyelenggaraan pemerintahan daerah yang sejalan dengan prinsip tata kelola pemerintah yang baik (good governance). Khususnya dalam menggali dan mengelola seluruh potensi pajak dan retribusi, pemerintah daerah dapat memberikan insentif sebagai tambahan penghasilan bagi Instansi pelaksana pemungut pajak dan retribusi yang mencapai kinerja tertentu.

Potensi pajak dan retribusi berkaitan langsung dengan aktivitas ekonomi sektoral dan sistem serta kemampuan aparatur pemerintah daerah untuk menggali sumber-sumber pajak dan retribusi potensial yang dapat dijadikan sebagai basis utama pendapatan asli daerah.

Strategi pemungutan dengan optimalisasi hasil adalah dengan melakukan intensifikasi terhadap objek atau sumber pendapatan daerah yang sudah ada melalui penghitungan potensi dengan penyusunan sistem informasi basis data potensi. Dengan melakukan efektifitas dan efisiensi sumber atau obyek pajak dan retribusi daerah, maka akan meningkatkan produktivitas PAD, tanpa harus melakukan perluasan sumber atau obyek pajak dan retribusi baru; yang memerlukan studi, proses dan waktu yang panjang. Estimasi potensi melalui penyusunan basis data yang berbentuk dan disusun dari variabel variabel yang merefleksikan masing-masing jenis penerimaan (pajak, retribusi dan penerimaan lain-lain) sehingga dapat menggambarkan kondisi potensi dari suatu jenis penerimaan.

Dalam pelaksanaan pembangunan daerah di Kabupaten Yahukimo, pemerintah daerah telah melakukan berbagai upaya untuk meningkatkan Pendapatan Asli Daerahnya. Upaya-upaya yang telah dilakukan adalah dengan menerbitkan Peraturan Daerah tentang jenis-jenis pajak dan retribusi yang dikelola oleh Pemerintah Kabupaten Yahukimo. Hanya saja, dalam proses pengimplementasian dari peraturan Daerah yang ada, pemerintah daerah masih terus mengalami hambatan.

Pajak daerah diatur dalam Peraturan Pemerintah RI Nomor 65 Tahun 2001 Pasal 1 Ayat 1, yang dimaksud dengan Pajak Daerah adalah iuran wajib yang dilakukan oleh orang pribadi atau badan kepada daerah tanpa imbalan langsung yang seimbang yang dapat dipaksakan berdasarkan peraturan perundangundangan yang berlaku yang digunakan untuk membiayai penyelenggaraan pemerintah daerah dan pembangunan daerah. 
Mardiasmo, (12;2008) Pajak Daerah adalah iuran wajib yang dilakukan oleh pribadi atau badan kepada daerah tanpa imbalan langsung yang seimbang, yang dapat dipaksakan berdasarkan peraturan perundang-undangan yang berlaku, yang digunakan untuk membiayai penyelenggaraan pemerintahan daerah dan pembangunan daerah.

Sedangkan menurut Rochmat Sumitro (48; 2009) Pajak Daerah adalah iuran rakyat kepada kas negara berdasarkan undang-undang (yang dipaksakan) dengan tidak mendapat jasa timbal balik (kontraprestasi) yang langsung dapat ditunjukan dan yang digunakan untuk membayar pengeluaran umum.

Berdasarkan pengertian di atas menurut Josef Riwu Kaho (2005:131), ciri ciri yang menyertai pajak daerah sebagai berikut: (a) Pajak Daerah berasal dari Pajak Negara yang diserahkan kepada daerah sebagai pajak daerah; (b) Penyerahan dilakukan berdasarkan perundang-undangan; (c) Pajak Daerah dipungut oleh daerah berdasarkan undang-undang dan atau peraturan hukum lainnya.

Dalam Pasal 1 angka 64 Undang-Undang Nomor 28 Tahun 2009 Tentang Pajak Daerah Dan Retribusi Daerah dijelaskan yang dimaksud dengan retribusi daerah yang selanjutnya disebut retribusi adalah pungutan daerah sebagai pembayarn atas jasa atau pemberian izin tertentu yang khusus disediakan atau diberikan oleh Pemerintah Daerah untuk kepentingan orang pribadi atau Badan.

Menurut Boediono dalam bukunya Perpajakan Indonesia $(2001 ; 14)$ memberikan pengertian bahwa retribusi adalah pembayaran yang dilakukan oleh mereka yang menikmati jasa negara secara langsung.

Menurut Juli Panglima Saragih (2002;65) Retribusi Daerah merupakan salah satu jenis penerimaan daerah yang dipungut sebagai pembayaran atau imbalan langsung atas pelayanan yang diberikan oleh Pemerintah Daerah kepada masyarakat.

Devas (1989), mengemukakan lima tolok ukur untuk menilai pajak daerah, yaitu Yield, equity, economic efficiency, ability to implement, dan suitability as a local source. Kelima tolok ukur tersebut telah digunakan untuk menilai pajak daerah di Indonesia, yang diberlakukan melalui Undang-Undang Pajak Daerah nomor 5 tahun 1974., Yaitu pajak kendaraan bermotor, pajak tontonan, pajak hotel dan restoran, pajak lampu jalan, pajak pendaftaran perusahaan, pajak iklan, pajak potong hewan, pajak bangsa asing, pajak radio, dan pajak kendaraan tidak bermotor. Sebagaimana dikemukakan oleh Rochmad Sumitro dalam Riwu Kaho (1997) bahwa pajak daerah adalah pajak yang dipungut oleh daerah-daerah swatantra. Padahal selalu terjadi perdebatan apakah pemerintah daerah berhak untuk mengambil pajak atau tidak. Sebagian menyetujui pemerintah regional 
(pemerintah daerah) menarik pajak dan sebagian lainnya tidak setuju daerah menarik pajak. Untuk menjembatani dua pendapat tersebut muncul berbagai solusi. Salah satu diantaranya adalah pendapat Devas di atas, yaitu pemerintah daerah dapat menarik pajak asalkan memenuhi kelima tolok ukur tersebut.

Yield (Hasil Pemungutan Pajak dan Retribusi Daerah). Pajak daerah memiliki dua fungsi, yaitu fungsi budgetair dan fungsi reguleerend. Pajak yang berfungsi budgetair adalah pajak yang menghasilkan banyak penerimaan pajak. Sedangkan pajak yang berfungsi reguleerend adalah pajak yang tidak memperhatikan apakah hasilnya memadai atau tidak, yang menjadi perhatian adalah kefungsian untuk mengatur suatu hal. Melihat dua karakteristik tersebut, dapat ditarik kesimpulan bahwa pajak yang budgetair pasti ditarik ke pemerintah yang lebih tinggi, sedangkan daerah hanyalah diberi pajak yang berfungsi reguleerend, dan tidak memiliki kemampuan untuk memperkuat posisi keuangan daerah. Namun demikian, tidak semua pajak daerah nonbudgetair. Banyak juga pajak daerah yang budgetair. Contohnya pajak hotel dan Pajak Golongan C di Kabupaten Yahukimo merupakan kontributor terbesar bagi PAD, dimana PAD mencapai $40 \%$ dari total penerimaan keuangan daerah. Di berbagai kabupaten, pajak penerangan jalan merupakan pajak dengan hasil terbesar di atas penerimaan pajak daerah lainnya. Dengan demikian, tetap diperlukan suatu pembahasan mengenai pajak daerah dari fungsi budgetair.

Equity (Keadilan Pajak dan Retribusi). Menurut Musgrave \& Musgrave (1989), arti penting keadilan terdapat pada kenyataan bahwa setiap orang harus mendapat bagian yang layak dalam kegiatan pemerintah yang mereka biayai sendiri. Namun sampai saat ini tidak diperoleh kepastian mengenai apa yang dimaksud dengan bagian yang layak. Biasanya orang menilai keadilan berdasarkan dua pendekatan, pertama adalah pendekatan manfaat dan kedua pendekatan kemampuan membayar. Berdasarkan pendekatan kemampuan membayar ini, dikenal istilah keadilan horizontal dan keadilan vertikal.

Adapun yang dimaksudkan keadilan horizontal menurut Devas (1988) adalah beban pajak haruslah sama benar antara berbagai kelompok yang berbeda tetapi dengan kedudukan ekonomi yang sama. Sedangkan keadilan vertikal adalah kelompok yang memiliki sumber daya yang besar membayar lebih banyak daripada yang memiliki sumber daya kecil.

Namun, sebagai suatu catatan, menurut Rossen, (1988), pemikiran mengenai keadilan dalam prinsip perpajakan adalah pemikiran tradisional. Sebab 
prinsip keadilan dalam perpajakan daerah, bahkan prinsip-prinsip lainnya, dapat digambarkan dalam hubungan antara pajak dengan social welfare funtion. Dengan kata lain, sebagai ganti atas prinsip keadilan, maka telah diintrodusir social welfare function yang dikaitkan dengan perpajakan daerah. Artinya berapapun pajak daerah ditetapkan, asal social welfare tidak mengalami penurunan, maka suatu penetapan pajak dikatakan tidak memiliki masalah dalam keadilan pungutan.

Economic Efeciency (Efesisensi Ekonomi). Pajak, dapat menjadi penghambat perkembangan dan pertumbuhan perekonomian. Sebab, pajak menyerap pendapatan masyarakat, akibatnya perputaran ekonomi yang semula berputar dengan cepat menjadi lebih lambat. Melalui keseimbangan dan hubungan antara pendapatan dengan pengeluaran keseluruhan, maka dapat diketahui bahwa pendapatan terbentuk dari pengeluaran konsumsi masyarakat, pengeluaran tabungan masyarakat, dan pengeluaran pajak.

Apabila dinotasikan, sebagai berikut :

karena

Sehingga

Atau

Dimana : (pengeluaran keseluruhan), $\mathrm{C}$, $\mathrm{T}=$ taxes (pajak)

Dari persamaan (4), dapat diketahui bahwa apabila pajak ditingkatkan, sedangkan pendapatan tetap, maka konsumsi dan tabungan menurun, dengan demikian terjadi efek kontraksi ekonomi akibat pajak. Demikian pula sebaliknya, penurunan pajak, sedangkan pendapatan tetap, maka konsumsi dan tabungan meningkat, dan terjadi efek ekspansi akibat pajak.

Ability to Implement (Kemampuan Melaksanakan). Kelayakan suatu daerah untuk melaksanakan pungutan dapat diketahui dari beberapa kriteria, yaitu apakah daerah tersebut memang daerah yang tepat untuk suatu pajak dibayarkan, tempat memungut pajak adalah tempat akhir beban pajak, dan pajak tidak mudah dihindari. Apabila suatu daerah memiliki ketiga kriteria tersebut, maka daerah tersebut layak sebagai daerah pemungut pungutan daerah. Kelayakan tersebut akan terlihat dengan kemampuan politis daerah untuk memungut pajak dan retribusi daerah, yaitu pemungutan pajak dan retribusi daerah didukung oleh seluruh lapisan masyarakat, terutama wajib pajak. Selanjutnya, kemampuan 
secara politis akan diimplementasiikan dalam kemampuan administrasi pemungutan pajak dan retribusi daerah.

Hasil dari kelayakan dan kemampuan administrasi tersebut, seharusnya terlihat dalam hubungan antara potensi dan realisasi penerimaan pungutan daerah. Semakin tinggi realisasi penerimaan pungutan daerah dibandingkan dengan potensi penerimaannya, menunjukkan bahwa daerah memiliki kemampuan untuk melaksanakan suatu pungutan. Selain itu, kemampuan suatu daerah untuk melaksanakan suatu pungutan dapat dibandingkan kemampuan daerah lain untuk melaksanakan pungutan tersebut. Sebab kemampuan melaksanakan tersebut bersandar pada kelayakan daerah. Oleh karena itu, apabila suatu daerah memiliki kelayakan memungut suatu pungutan dibandingkan daerah lain, maka seharusnya daerah tersebut memiliki kemampuan melaksanakan suatu pungutan dibandingkan dengan daerah lainnya.

\section{Suitability As A Local Source (Kesesuaian Sebagai Penerimaan Daerah).}

Yang dimaksud dengan suitability as a local source (kesesuaian pungutan sebagai penerimaan daerah) dapat dilihat dari dua hal, pertama dibandingkan dengan daerah yang sejenis, dan kedua dibandingkan dengan daaerah yang lebih tinggi. Keseuaian dari hal yang pertama, yaitu kesesuaian dibandingkan dengan daerah sejenis sebenarnya paralel dengan ability to implement (kemampuan melaksanakan).

Dengan kata lain, apabila suatu pungutan di daerah memiliki nilai ekonomi berupa daerah tersebut mampu untuk melaksanakan pajak tersebut, maka pada saat yang sama pungutan tersebut memiliki nilai ekonomi berupa sesuai sebagai pungutan daerah. Dan sebaliknya, apabila suatu pungutan tidak memiliki nilai kemampuan untuk melaksanakan, maka pada saat yang sama daerah tersebut tidak sesuai sebagai tempat pemungutan pungutan daerah.

Adapun hal yang kedua, yaitu kesesuaian dengan daerah yang lebih tinggi, adalah bahwa sesuai dengan berbagai kefungsian pemerintahan, setiap tingkatan pemerintahan telah memiliki aturan mengenai pungutan yang boleh ditarik. Ada pungutan yang bisa ditarik oleh pemerintah pusat, ada yang dapat ditarik oleh pemerintah propinsi, dan ada pungutan yang dapat ditarik oleh pemerintah daerah. Dan 'diharamkan' terjadinya pemungutan dua kali atau lebih, artinya apabila suatu pungutan telah ditarik pemerintah pusat, tidak boleh ditarik lagi oleh pemerintah propinsi dan atau pemerintah daerah. 
Oleh karena itu, dapat dipastikan, bahwa suatu pungutan pastilah sesuai dengan daerah yang lebih tinggi, yaitu tidak mungin terjadi 'rebutan' pemungutan pajak. Pada saat ini, semua pajak daerah, dilihat dari sudut kemauan politik, dapat dilaksanakan. Sebab, dalam UU nomor 22 tahun 1999 mengenai Otonomi Daerah, disebutkan bahwa daerah sangat mandiri, tidak terintervensi olen pusat. Setiap peraturan dibuat oleh daerah itu sendiri melalui legislasi DPRD setempat. Kalaupun dalam UU nomor 18 tahun 1997 disebutkan bahwa setiap legislasi pajak dan retribusi daerah harus mendapat izin dari menteri dalam negeri, namun sudah banyak permintaan untuk merevisi UU nomor 18 tahun 1997 dan sudah dituangkan dalam UU nomor 34 tahun 2000.

Dengan demikian, apabila peraturan daerah mengenai pungutan tidak bertentangan dengan kedua undang-undang tersebut, yaitu UU nomor 18 tahun 1997 dan Undang-undang nomor 34 tahun 2000 maka peraturan daerah tersebut disebut sesuai sebagai penerimaan daerah (suitability as a local source).

Berdasarkan judul penelitian dalam tesis ini yaitu Potensi Pajak dan Retribusi Daerah di Kabupaten maka yang di maksud Potensi Pajak dan retribusi Daerah adalah pencapaian penerimaan pajak dan retribusi daerah sesuai yang diharapkan yang bedampak potensi dari Pajak dan retribusi daerah tersebut. Potensi yang dimaksud deiukur dengan menggunakan lima tolak ukur pajak dan retribusi daerah, yaitu Yield (Hasil pungutan Pajak dan Retribusi), Equity (Keadilan Pajak dan Retribusi Daerah), Economic Efeciency ( Efesisensi Ekonomi), Ability to Implement (Kemampuan Untuk Melaksanakan), Suitability As a Local Source (Keseuaian Sebagai Penerima Daerah). Sehingga kelima tolak ukur tersbut di simpulkan berpotensi dan tidak berpotensi bagi daerah Kabupaten Yahukimo.

\section{Gambar 1.1 Kerangka Pemikiran Penelitian}

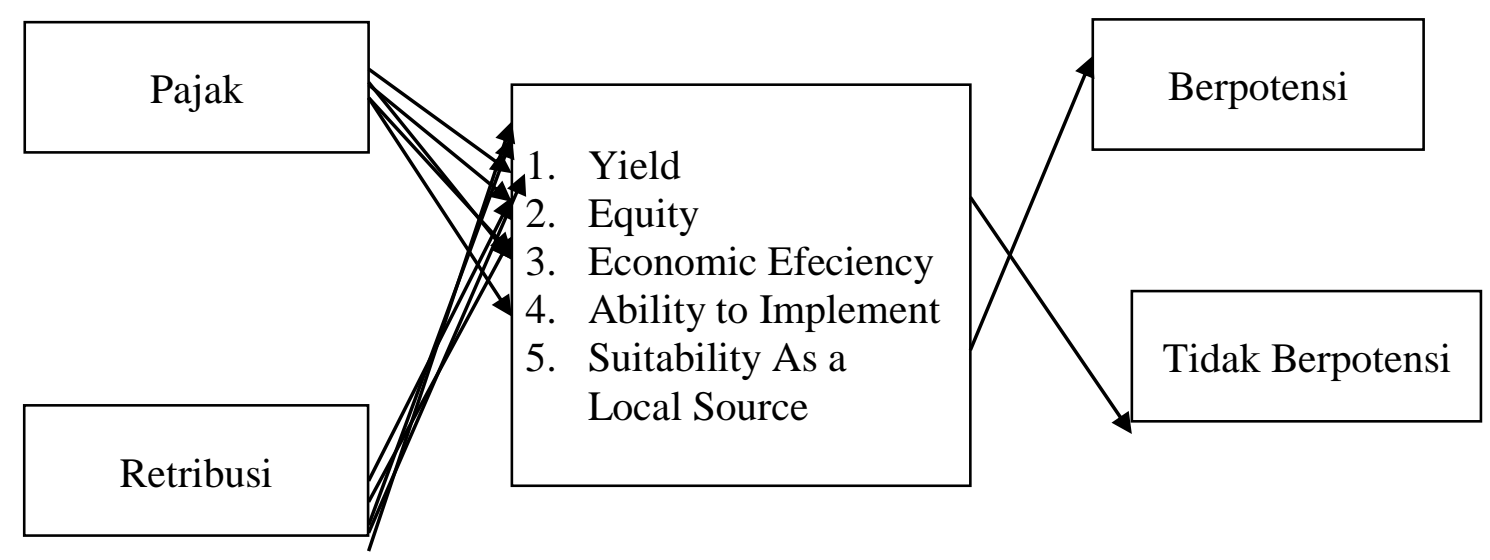




\section{METODE PENELITIAN}

Dalam penelitian ini, metode yang digunakan adalah metode peneltian deskriptif yaitu metode penelitian yang dilakukan melalaui pengamatan untuk mendapatkan keterangan-keterangan terhadap suatu masalah tertentu serta untuk mendapatkan gambaran tentang pengelolahan pajak dan retribusi daerah dalam rangka meningkatkan Pendapatan Asli Daerah (PAD) Kabupaten Yahukimo.

Kecenderungan untuk menggunakan metode penelitian ini, didasarkan pada pertimbanagan bahwa metode ini dianggap sangat relevan dengan materi penulisan Tesis, karena penelitian yang dilakukan hanya bersifat deskriptif, yaitu menggambarkan apa adanya dari kejadian yang diteliti. Selain itu, guna memperoleh data yang obyektif dan valid dalam rangka memecahkan permasalahan yang ada.

\section{HASIL DAN PEMBAHASAN}

\section{Yield (Hasil)}

Untuk menilai hasil penerimaan pajak dan retribusi daerah di Kabupaten Yahukimo, maka dipergunakan dua penilaian, yaitu : (a) Elastisitas penerimaan pajak dan retribusi daerah terhadap pengeluaran rutin pemerintah daerah. (b) Elastisitas penerimaan pajak dan retribusi daerah terhadap PDRB

Digunakannya dimensi pertumbuhan sebagai alat untuk menilai hasil (Yield), diharapkan memberikan gambaran kongkrit hasil (Yield) penerimaan pajak dan retribusi daerah. Sebab hasil (Yield) nominal penerimaan pajak dan retribusi daerah pada periode kesalahan teknis maupun kesalahan sumber daya manusia. Mengingat pajak dan retribusi lebih banyak digunakan untuk membiayai pengeluaran rutin, maka seharusnya terdapat hubungan yang elastis antara pajak dan retribusi daerah dengan pengeluaran rutin pemerintah daerah dan karena pengeluaran rutin digunakan untuk membiayai aktivitas operasional pembangunan daerah, maka seharusnya pajak dan retribusi elastis terhadap PDRB. Artinya perubahan penerimaan hasil (Yield) pada pajak dan retribusi daerah seharusnya menyebabkan perubahan pengeluaran rutin dan PDRB dalam prosentase yang lebih besar. Oleh karena itu, untuk menilai hasil penerimaan pajak dan retribusi daerah Kabupaten Yahukimo berpotensi atau tidak, digunakan ukuran : (a) Sangat potensial jika nilai elasitisitas $>+1$; (b) Berpotensi berpotensi jika nilainya $>0$, (3) Tidak berpotensi jika nilai < -0; (4) Sangat tidak berpotensi jika nilainya <-1

Berbagai pajak dan retribusi daerah yang memberikan hasil nominal besar terhadap PADS (Penerimaan Asli Daerah Sendiri), ternyata sangat tidak memiliki potensi hasil (Yield). Hasil perhitungan elastisitas sebagai berikut: 
Tabel 1.1 Potensi Hasil (Yield) Pajak dan Retribusi di Kabupaten Yahukimo

\begin{tabular}{|l|l|l|l|}
\hline Jenis Pajak dan Retribusi & Epdrb-pr & Ebr-pr & Potensi \\
\hline Pajak Golongan C & 0,08 & 0,19 & Berpotensi \\
\hline Retribusi Pelayanan Kesehatan & $-0,18$ & $-0,42$ & Tidak Berpotensi \\
\hline Pajak Hotel & 0,07 & 0,18 & Berpotensi \\
\hline Retribusi parkir bandara & $-0,38$ & $-0,91$ & Sangat tidak berpotensi \\
\hline Retribusi Sewa Ruko & 0,37 & 0,89 & Berpotensi \\
\hline Retribusi Sewa Listrik & 0,02 & 0,05 & Berpotensi \\
\hline Penyertaan lelang & 0,22 & 0,52 & Berpotensi \\
\hline Retribsui ijin gangguan & 0,84 & 2,03 & Sangat Berpotensi \\
\hline Ret. Peredaran hasil hutan & - & - & - \\
\hline Sumbangan pihak ke 3 & 0,06 & 0,15 & Berpotensi \\
\hline Sumber Dat Prim dian & & &
\end{tabular}

Sumber :Data Primer diolah

Keterangan:

- Epdrb-pr : Elastisitas antara PDRB dengan Pajak dan Retribusi daerah

- Ebr-pr : Elastisitas antar belanja rutin dengan Pajak dan Retribusi

Daerah

Dari data diatas dapat disimpulkan bahwa, nilai elastisitas yang rendah terdapat pada retribusi parkir bandara, nilai elastisitas PRDB terhadap Pajak dan Retribusi sebesar -0,38 sedangkan nilai elastisitas Belanja Langsung terhadap Pajak dan Retribusi sebesar -0,91. Hal ini memiliki nilai elastisitas terendah disebakan oleh menurunnya penghasilan dari retribusi parkir bandara di tahun 2015. Kondisi Bandara di Daerah Kabupaten Yahukimo, sedang mengalami perbaikan dari segi fasilitas. Namun perbaikan maupun renovasi tersebut terhambat sehingga penggunaan halaman parkir tidak digunakan secara optimal. Selain itu retribusi pelayanan kesehatan tergolong tidak berpotensi. Hal ini disebabkan karena bertolak belakang dengan program kesehatan gratis bagi masyarakat, misalnya program BPJS. Sehingga penghasilan retribusi pelayanan kesehatan menurun.

Adapun pajak dan retribusi daerah yang tergolong berpotensi yaitu, Pajak Golongan C, pajak Hotel, Retribusi Sewa Ruko, Penyertaan Lelang, dan Sumbangan Pihak Ke-3.

Elastisitas yang paling tinggi ada pada retribusi ijin gangguan dengan nilai elatisitas PDRB terhadap pajak dan Retribusi sebesar 0,84 dan elastisitas Belanja langsung sebesar 2,03. Retribusi ijin gangguan tergolong sangat berpotensi, retribusi ini merupakan pungutan dari setiap jenis usaha yang terdapat di daerah Kabupaten Yahukimo. Berdasarkan rekapan data pajak retribusi, terdapat 417 jenis usaha. Data jumlah usaha dan jeni usaha, sebagai berikut: 
Tabel 1.2 Jumlah jenis Usaha Di Kabupaten Yahukimo

\begin{tabular}{|l|l|l|}
\hline No & Jenis Usaha & Jumlah Jenis Usaha \\
\hline 1 & Kategori Toko & 69 \\
\hline 2 & Kategori Kios & 221 \\
\hline 3 & Kategori Bengkel & 25 \\
\hline 4 & Kategori Hotel, Wisma, dan Kos & 16 \\
\hline 5 & Kategori Cafe, Rumah Makan, dan Warung Makan & 64 \\
\hline 6 & Kategori Penjahit & 4 \\
\hline 7 & Kategori Apotik & 5 \\
\hline 8 & Kategori Salon dan Pangkas Rambut & 6 \\
\hline 9 & Kategori Fotocopy dan Warnet & 12 \\
\hline 10 & Kategori BBM & 5 \\
\hline
\end{tabular}

Sumber : Data Rekapan Pajak/ Retribusi

Dari tabel diatas dapat disimpulakan bahwa retribusi ijin gangguan bersumber dari banyaknya jenis usaha di Kabupaten yahukimo. Retribusi tersebut di pungut sesuai dengan modal dan luas wilayah yang dimiliki setiap jenis usaha.

Hasil penelitian ini berbeda dengan penelitian yang dilakukan oleh Riyadi dan Setyawan (2002), yang melakukan penelitian di daerah Kabupaten Sukoharjo. Hasil dari penelitian tersebut adalah nilai pertumbuhan hasil (Yield) yang sangat berpoytensi terdapat pada pajak Pemanfaatan ABT dan APT, dan Retribusi Perun. Tanah. Sedangkan yang sangat tidak berpotensi adalah Pajak Penerangan jalan, Retribusi Biaya Cetak KTP, Retribusi Pelayanan Kesehatan dan Retribusi Terminal. Namun terdapat persamaan pada pajak hotel antara Kabupaten Sukoharjo dan Kabupaten Yahukimo yang menemukan hasil bahwa pajak hotel tersbut memeliki pertumbuhan hasil (Yield) yang berpotensi.

Ability to Implement (Kemampuan Melaksanakan). Untuk mengetahui sejauh mana pemerintah daerah Kabupaten Sukoharjo dapat melaksanakan pengelolaan pajak dan retribusi daerah digunakan dua alat, yaitu :

a. Perbandingan antara potensi dan realisasi penerimaan pajak dan retribusi daerah sejak tahun 2014 di Kabupaten Yahukimo.

b. Perbandingan antara potensi dan realisasi penerimaan pajak dan retribusi daerah sejak tahun 2015 di Kabupaten Yahukimo.

Dimana dipergunakan alat analisis sebagai berikut :

a. Sangat berpotensi untuk dilaksanakan di kabupaten Yahukimo apabila perbandingan potensi dan realisasi diatas $110 \%$ maka dkatakan berpotensi.

b. Tidak Berpotensi apabila kurang dari $110 \%$ 
Dipergunakannya alasan perbandingan antara potensi dan realisasi penerimaan pajak dan retribusi daerah, dengan argumentasi hubungan antara potensi dan realisasi menunjukkan kemampuan melaksanakan perpajakan dan retribusi daerah. Kemampuan untuk mencapai potensi apalagi melebihi potensi menunjukkan bahwa pajak dan retribusi daerah tersebut mudah dilaksanakan. Semakin tinggi realisasi dibandingkan potensinya, berarti semakin terlihat adanya kemampuan pada daerah untuk melaksanakan pajak dan retribusi tersebut.

Hanya saja, pada penelitian ini digunakan patokan $110 \%$. Yaitu untuk disebut memiliki potensi untuk melaksanakan pajak dan retribusi daerah, berarti realisasi penerimaan pajak dan retribusi daerah minimal $110 \%$ dari potensinya. Adapun realisasi sebesar kurang dari 110\% dikhawatirkan 'terlalu mudah' dicapai, sehingga tidak dapat digunakan sebagai tolok ukur kemampuan untuk melaksanakan. Apalagi di bawah 100\% menunjukkan bahwa daerah tidak dapat melaksanakan pajak dan retribusi daerah tersebut.

Tabel 1.3 Perbandingan antara Potensi dan Penerimaan Tahun 2014

\begin{tabular}{|l|l|l|l|}
\hline Jenis Pajak & 2014 & $>110$ & Kesimpulan \\
\hline Pajak Golongan C & $138 \%$ & Lebih besar & Berpotensi \\
\hline Retribusi Pelayanan Kesehatan & $348 \%$ & Lebih besar & Berpotensi \\
\hline Pajak Hotel & $114 \%$ & Lebih besar & Berpotensi \\
\hline Retribusi parkir bandara & $140 \%$ & Lebih besar & Berpotensi \\
\hline Retribusi Sewa Rukop & $162 \%$ & Lebih besar & Berpotensi \\
\hline Retribusi Sewa Listrik & $153 \%$ & Lebih besar & Berpotensi \\
\hline Penyertaan lelang & $236 \%$ & Lebih besar & Berpotensi \\
\hline Retribsui ijin gangguan & $159 \%$ & Lebih besar & Berpotensi \\
\hline Ret. Peredaran hasil hutan & $135 \%$ & Lebih besar & Berpotensi \\
\hline sumbangan pihak ke 3 & $129 \%$ & Lebih besar & Berpotensi \\
\hline
\end{tabular}

Sumber : Data Primer diolah (Tahun 2014)

Tabel 1.4 Perbandingan antara Potensi dan PenerimaanTahun 2015

\begin{tabular}{|l|l|l|l|}
\hline Jenis Pajak & 2015 & $>110$ & Kesimpulan \\
\hline Pajak Golongan C & $168 \%$ & Lebih Besar & Berpotensi \\
\hline Retribusi Pelayanan Kesehatan & $101 \%$ & Lebih Besar & Berpotensi \\
\hline Pajak Hotel & $220 \%$ & Lebih Besar & Berpotensi \\
\hline Retribusi parkir bandara & $42 \%$ & Lebih Kecil & Tidak berpotensi \\
\hline Retribusi Sewa Ruko & $122 \%$ & Lebih Besar & Berpotensi \\
\hline Retribusi Sewa Listrik & $149 \%$ & Lebih Besar & Berpotensi \\
\hline Penyertaan lelang & $168 \%$ & Lebih Besar & Berpotensi \\
\hline Retribsui ijin gangguan & $88 \%$ & Lebih Kecil & Tidak berpotensi \\
\hline Ret. Peredaran hasil hutan & $90 \%$ & Lebih Kecil & Tidak berpotensi \\
\hline sumbangan pihak ke 3 & $268 \%$ & Lebih Besar & Berpotensi \\
\hline
\end{tabular}

Sumber: Data primer diolah 
Pajak dan retribusi yang tidak berpotensi dan sangat tidak berpotensi untuk dilaksanakan, dikarenakan tidak menunjukkan keunggulan di Kabupaten Yahukimo. Khususnya ditahun 2015 ada beberapa jenis pajak dan retribusi yang persentasinya dibawah $110 \%$ yaitu, Retribusi Parkir Bandara, Retribusi ljin Gangguan dan Retribusi Peredaran Hasil Hutan. Menurunnya realisasi pajak dan retribusi pada Retribusi Parkir Bandara disebabkan adanya perbaikan halaman parkir oleh Pemerintah Daerah Kabupaten Yahukimo. Sehingga penggunaan halaman parkir tersebut terhambat. Disebabkan fasilitas yang belum memadai. Selain itu retribusi ljin Gangguan juga menurun, karena pihak yang berwenang untuk menagih retribusi ijin gangguan masih memberikan kelonggaran waktu bagi pemilik usaha di Kabupaten Yahukimo. Sehingga pembayaran retrubusi ijin gangguan di tahun 2015, mengalami penurunan.

Sedangkan pada tahun 2014 secara keseluruhan berpotensi yaitu meliputi, Pajak Golongan C, retribusi pelayanan kesehatan, Pajak Hotel, Retribusi Parkir Bandara, Retribusi Sewa Listrik, Retribusi Sewa Ruko, Penyertaan Lelang ljin gangguan, Retribusi Peredaran Hasil Hutan, dan Sumbangan pihak ke-3. Secara keseluruhan pajak dan retribusi di tahun 2014, memiliki nilai persentasi pertumbuhan diatas $110 \%$.

Berdasarkan penelitian yang dilakukan oleh Riyadi dan Setyawan (2002), potensi dan realisasi di Kabupaten sudah cukup baik, karena mencapai 72\% yang tergolong pajak dan retribusi yang berpotensi. Sama halnya dengan kabupaten Yahukimo, pajak dan retribusi yang bepotensi sebesar $70 \%$. Sedangkan $30 \%$ tidak berpotennsi, di sebakan oleh ketidapastian lingkungan dan faktor lainnya.

Economic Efeciency (Efesiensi Ekonomi). Untuk mengetahui apakah penerapan pajak dan retribusi daerah berpotensi menerapkan prinsip efisiensi atau tidak, maka dipakai tolok ukur berupa perbandingan antara biaya pajak dan retribusi dengan total cost. Hanya saja setelah dilakukan penyebaran daftar pertanyaan kepada berbagai perusahaan diperoleh kesimpulan bahwa ada kemungkinan data biaya, baik biaya tetap, biaya tidak tetap, ataupun total cost yang tidak dituliskan responden.

Namun, dalam wawancara dengan para responden, mereka selalu mengeluhkan dan menakutkan otonomi daerah bakal menyebabkan usaha mereka mengalami kemunduran. Oleh karena itu, untuk mengetahui apakah suatu pungutan pajak dan retribusi di Kabupaten Yahukimo menyebabkan economic disefficiency atau tidak, digunakan pendapat dari sampel wajib pajak dan retribusi daerah. Kepada mereka ditanyakan tiga kelompok pertanyaan, yaitu 
: (1) Apakah pajak dan retribusi daerah membebani biaya mereka atau tidak; (2) Apakah otonomi merupakan ancaman atau bukan; (3) Apa yang menghalangi kelangsungan usaha usaha daerah

Wajib pajak dan retribusi daerah menganggap otonomi daerah sebagai acaman, sebab dalam pandangan wajib pajak, momen otonomi daerah akan digunakan pemerintah daerah untuk menaikkan penghasilan asli daerah sendiri (PADS) dari pajak dan retribusi daerah. Namun, pada faktanya proporsi antara biaya pajak dan retribusi daerah dengan total biaya dikeluarkan suatu usaha daerah relatif kecil. Bahkan, para wajib pajak dan retribusi daerah menunjuk faktor nasional, seperti krisis ekonomi dan moneter dan kenaikan harga-harga, yang mempunyai pengaruh diseficiency terhadap kelangsungan usaha di daerah. Dengan demikian dapat disimpulkan bahwa pajak dan retribusi daerah memiliki potensi efisiensi dan tidak menyebabkan disefisiensi ekonomi. Adapun data yang menunjukkan pendapat para responden sebagai berikut :

Tabel 1.5 Pandangan Wajib Pajak DaerahTerhadap Efisiensi Ekonomi

\begin{tabular}{|l|c|c|c|}
\hline \multicolumn{1}{|c|}{ Nama Usaha dan Pemilik } & $\begin{array}{c}\text { Anggapan } \\
\text { biaya pajak } \\
\text { dan Retribusi }\end{array}$ & $\begin{array}{c}\text { Anggapan } \\
\text { Otonomi } \\
\text { Daerah }\end{array}$ & $\begin{array}{c}\text { Anggapan } \\
\text { Penghalang } \\
\text { Usaha }\end{array}$ \\
\hline PT. Bintang Timur Mandiri/Nanang S. & Kecil & Ancaman & Kenaikan Harga \\
\hline PT. PJPR / Samuel Kadang & Kecil & Ancaman & Kenaikan Harga \\
\hline PT. Ferolina/Arif Kobek & Kecil & Ancaman & Kenaikan Harga \\
\hline PT Lintas Belantara / Marnita T. & Kecil & Ancaman & Kenaikan Harga \\
\hline CV. Corona / Ria Megawani & Kecil & Ancaman & Kenaikan Harga \\
\hline CV. Lemba Hijau / Meliati K. & Kecil & Ancaman & Kenaikan Harga \\
\hline CV. Duta Mandiri / Alfret N. & Kecil & Ancaman & Kenaikan Harga \\
\hline CV. Dimal / Boli N & Kecil & Ancaman & Kenaikan Harga \\
\hline CV. Bombong L. / Mardiana P & Kecil & Ancaman & Kenaikan Harga \\
\hline
\end{tabular}

Sumber: Data Primer diolah

Hasil penelitian ini sejalan dengan penelitian yang dilakukan oleh Riyadi dan

Setyawan (2002), yang mengemukakan bahwa adanya otonomi daerah mungkin menjadi sebuah ancaman kenaikan harga demi meningkatkan pendapatan asli Daerahnya, namun menurut kondisi dan fakta yang ada para pengusaha menganggap bahwa pajak dan retribusi daerah tidak berpotensi menghambat kelangsungan usaha.

Equity (Keadilan). Untuk mengetahui apakah penerapan pajak dan retribusi daerah berpotensi menerapkan prinsip keadilan atau tidak, maka dipakai tolok ukur apakah perusahaan dengan skala usaha besar membayar pajak dan retribusi 
daerah lebih besar dari pada usaha yang berskala kecil. Adapun hasil dari pengolahan data, diperoleh kesimpulan sebagai berikut :

a. Usaha besar membayar pajak dan retribusi daerah lebih banyak daripada usaha menengah dan kecil, sehingga pajk dan retribusi daerah menunjukkan nilai keadilan

b. Nilai keadilan juga terlihat pada perbandingan pembayaran pajak dan retribusi daerah antara usaha menengah dan usaha kecil. Dimana usaha menengah membayar pajak dan retribusi daerah lebih banyak daripada usaha kecil.

Hal itu terlihat dengan jelas, dengan mengelompokkan berdasarkan jenis usaha yang homogen. Dari sini terlihat bahwa pada usaha sejenis, usaha menengah membayar pajak dan retribusi daerah lebih besar dibandingkan dengan usaha kecil.

Dibawah ini terdapat tabel yang menjelaskan nama usaha sesuai dengan pengelompokan jenis usahanya di daerah Kabupaten Yahukimo. Menurut data jenis usaha, terdapat 417 usaha yang terdiri dari 10 sektor usaha dengan klasifikasi usaha terdapat pada tabel sebelumnya, yaitu tabel 4.2. Dalam penelitian ini, peneliti hanya mengambil beberapa sampel. Hal ini disebabkan karena jumlah pungutan dari setiap jenis usaha maupun per sektor tidak terlalu jauh berbeda.Berdasarkan jumlah jenis usaha yang terdapat di Kabupaten Yahukimo terdiri dari 417 jenis ussaha. Namun dalam penelitian ini tidak dicantumkan seluruhnya.

Hasil penelitian ini sejalan dengan penelitian yang dilakukan oleh Riyadi dan Setyawan (2002), yang menemukan hasil bahwa pengelompokan usaha yang sejenis misalnya warung makan, memiliki besar tarif pungutan yang berbedabeda. Perbedaan tarif didasari oleh skala usaha dan penghasilan dari usaha tersebut.

Hasil yang sama juga didapat dari penelitian di Kabupaten Yahukimo, yang menunjukkan hasil bahwa tarif warung makan yang memiliki tarif terendah, sedangkan yang tertinggi ada pada usaha meubel. Besar kecilnya tarif pungutan pajak ini berdasarkan luas wilayah dan juga besar modal yang dimilik oleh si pemilik usaha.

\section{Suitability As a Local Source (Keseuaian Sebagai Pendapatan daerah).} Kesesuaian sebagai pendapatan daerah adalah seberapa besar daerah berhak untuk mendapatkan suatu pajak dan retribusi daerah. Apabila hanya sebagian saja yang berhak dimiliki oleh daerah, sedangkan sebagian lainnya menjadi hak 
pemerintahan yang lebih tinggi maka dikatakan bahwa pajak dan retribusi daerah tersebut tidak sesuai dengan pendapatan daerah. Dan karena seberapa besar yang menjadi hak pemerintah daerah atau seberapa hak pemerintah yang lebih tinggi ditentukan berdasarkan undang-undang, maka untuk mengetahui kesesuaian pajak dan retribusi daerah sebagai pendapatan daerah, digunakan pendekatan kesesuaian dengan undang-undang pajak dan retribusi daerah.

Pada saat ini undang-undang yang mengatur pajak dan retribusi daerah adalah UU nomor 28 tahun 2009, oleh karena itu pajak dan retribusi daerah di Kabupaten Yahukimo harus diteliti kesesuaiannya dengan undang-undang tersebut . Sehingga untuk kesesuaian sebagai pendapatan daerah digunakan ukuran sebagai berikut:

a. Dikatakan berpotensi sesuai sebagai pendapatan daerah bila pajak dan retribusi daerah tidak bertentangan dengan undang-undang.

b. Dikatakan tidak berpotensi jika pendapatan daerah bila pajak dan retribusi daerah bertentangan dengan undang-undang.

Untuk mendapatkan kesimpulan kesesuaian peraturan daerah mengenai pajak dan retribusi terhadap Undang-Undang nomor 28 Tahun 2009, diajukan beberapa pertanyaan kepada beberapa key person (responden kunci), dari kalangan ahli hukum, kalangan eksekutif dan legislatif di Kabupaten Yahukimo yang terlibat dalam pembuatan dan revisi peraturan daerah mengenai pajak dan retribusi daerah.

Dari berbagai jawaban responden kunci, ditemukan bahwa tidak ada pajak dan retribusi daerah di Kabupaten Yahukimo yang bertentangan dengan kedua jenis undang-undang. Kalaupun ada keinginan revisi peraturan daerah mengenai pajak dan retribusi daerah lebih disebabkan pada kenyataan bahwa (1) Peraturan daerah ditetapkan sudah kadaluwarsa atau (2) Besar penetapan pajak dan retribusi daerah belum sesuai dengan inflasi.

Tabel 1.6 Kesesuaian Sebagai Sumber Penerimaan Daerah

\begin{tabular}{|c|c|c|}
\hline Jenis Pajak & $\begin{array}{c}\text { Kesesuaian } \\
\text { UU NO.28 TAHUN } 2009\end{array}$ & Kesimpulan \\
\hline Pajak Golongan C & Sesuai & Berpotensi \\
\hline Retribusi Pelayanan Kesehatan & Sesuai & Berpotensi \\
\hline Pajak Hotel & Sesuai & Berpotensi \\
\hline Retribusi parkir bandara & Sesuai & Berpotensi \\
\hline Retribusi Sewa Rukop & Sesuai & Berpotensi \\
\hline Retribusi Sewa Listrik & Sesuai & Berpotensi \\
\hline Penyertaan lelang & Sesuai & Berpotensi \\
\hline Retribsui ijin gangguan & Sesuai & Berpotensi \\
\hline Ret. Peredaran hasil hutan & Sesuai & Berpotensi \\
\hline sumbangan pihak ke 3 & Sesuai & Berpotensi \\
\hline
\end{tabular}

Sumber : Data Primer diolah 
Berdasarkan data diatas dapat disimpulkan bahwa pungutan pajak dan retribusi di daerah Kabupaten Yahukimo sesuai dengan aturan yang berlaku, yaitu berdasarkan Undang-undang No 28 Tahun 2009 tentang Pajak Daerah dan Retribusi Daerah.

Hasil penelitian ini sejalan dengan penelitian yang dilakukan oleh Riyadi dan Setyawan (2002), yang menjelaskan bahwa tidak ada pajak dan retribusi yang bertentangan dengan Undang-undang yang berlaku.

Namun perbedaan penelitian ini yaitu terletak pada Undang-undang yang digunakan. Penelitian di daerah Kabupaten Sukahajo menggunakan Undangundang Nomor 34 Tahun 2000. Sedangkan penelitian di daerah Kabupaten Yahukimo menggunakan Undang-undang terbaru yaitu Undang-undang Nomor 28 Tahun 2009.

\section{KESIMPULAN DAN SARAN}

\section{Kesimpulan}

Berdasarkan potensi hasil dan atau kemampuan untuk dilaksanakan terdapat 2 (dua) pajak dan retribusi yang tidak berpotensi yaitu Retribusi Parkir Bandara, dan Retribusi Peredaran Hasil Hutan. Sedangkan Retribusi Pelayanan Kesehatan dan Retribusi ljin Gangguna pada Variabel Kemampuan Melaksanakan tergolong berpotensi, namun pada variabel hasil tidak berpotensi.

Variabel Economic Efeciency (Efesiensi Ekonomi), Equity (Keadilan) dan Suitability as a Local Source (Keseuaian Sebagai PAD) sama-sama tergolong berpotensi. Sebab pelaksanaan pungutan Pajak dan Retribusi di Kabupaten Yahukimo memiliki biaya pungutan yang relatif kecil, namun tidak dipungkiri bahwa adanya ketidakpastian lingkungan bisa menyebabkan kenaikan harga. Selain itu biaya pungutan dilaksanakan secara adil sesuai dengan luas wilayah dan modal para pemilik usaha. Adanya pajak dan retribusi tersbut tentu berdsarkan pada peraturan yang berlaku yaitu Undang-undang No. 28 Tahun 2009.

Faktor-faktor yang mempengaruhi kemampuan penerimaan dari pajak dan retribusi daerah adalah perkembangan demografi, seperti jumlah penduduk , jumlah pemilik usaha., fasilitas dan kesadaran membyara pajak dan retribusi.

\section{Saran}

Bagi Pemerintah, Segera memperbaiki dan menyediakan fasilitas yang baik khususnya perbaikan halaman parkir bandara, agar dapat digunakan sesegera mungkin, sehingga dapat meningkatkan jumlah retribusi parkir bandara di Kabupaten Yahukimo. 
Perilaku ekonomi dan organisasional aparat pemerintah daerah pemungut pajak dan retribusi harus diperbaiki, sedemikian rupa sehingga dilihat dari ability to implement, perilaku tersebut nampak dalam menentukan dan merealisasikan hubungan antara target, potensi, dan realisasi.

Bagi Masyarakat, agar lebih memiliki kesadaran untuk membayar pajak dan retribusi sesuai sesuai jatuh tempo yang ditentukan. Mengingat hasil pungutan tersebut sangat berpengaruh dalam meningkatkan penghasilan bagi Kabupaten Yahukimo.

Bagi Peneliti Selanjutnya, melakukan penelitian di daerah Kabupaten maupun kota-kota yang memiliki banyak sumber penermaan Pajak dan Retribusi. Selain itu membandingkan hasil penelitian dengan Kabupaten yang lain juga sangat diperlukan.

\section{DAFTAR PUSTAKA}

Adhitya Wardhono, dkk. 2012. Kajian Pemetaan dan Optimalisasi Potensi Pajak Dalam Rangka Meningkatkan Pendapatan Asli Daerah (PAD) di Kabupaten Jember, J@TI Undip, Vol VII, No.2, Mei 2012.

Agung Riyardi, Anton Agus Setyawan, Didit Purnomo. 2002. Potensi Pajak Dan Retribusi Daerah Di Kabupaten Sukoharjo, Laporan Penelitian: Fakultas Ekonomi Universitas Muhammadiyah Surakarta.

Algifari. 2003. Statistik Induktif, Yogyakarta : UPP AMP YKPN.

Arikunto, w. 1993. Prosedur Penelitian Suatu Pendekatan Praktik. Bina Aksara. Jakarta.

Arsyad, Lincolyn. 1999. Pengantar Perencanaan dan Pertumbuhan Ekonomi Daerah, BPFE-UGM, Yogyakarta

Brotodihardjo, Santoso. 1993. Pengantar Ilmu Hukum Pajak, Bandung : PT Eresco Bandung.

Davey, KJ. 1998. Pembiayaan Pemerintah Daerah : Praktek-Praktek Internasional dan Relevansi bagi Dunia Ketiga, diterjemahkan oleh Amanullah, Jakarta UI Press.

Devas, Nick, dik. 1989. Keuangan Pemerintah Daerah di Indonesia, UI-Press, Jakarta

Elfianti, Lis. 2009. Potensi dan Strategi Pengelolaan Pajak dan Retribusi Daerah Studi Kasus di Kabupaten Sijunjung, Tesis : Program Pascsarjana Universitas Andalas. Padang.

Ferdinan, A.T. 2006. Motode Penelitian Manajemen, BP Universitas Diponegoro Semarang. 
Hadjon, P. M. 1990. Perlindungan Hukum bagi Rakyat di Indonesia, Surabaya: Bina IImu

Himawan Estu Bagijo. 2011. Pajak dan Retribusi Daerah Sebagai Sumber Pendapatan Daerah (Studi Kasus di Kabupaten/Kota dan Pemerintah Propinsi di Jawa Timur), Jurnal PERSPEKTIF Volume XVI No. 1 Tahun 2001 Edisi Januari.

Jogiyanto. 2005. Sistem Informasi Strategik untuk Keunggulan Kompetitif, Penerbit Andi Offset : Yogyakarta.

Kaho, J.R. 1995. Prospek Otonomi Daerah di Negara Republik Indonesia, Jakarta : Raja Grafindo Persada.

Mangkoesoebroto, Guritno. 1998. Ekonomi Publik, Edisi Kedua Yogyakarta: BPFE-UGM.

Mardiasmo. 2002. Otonomi dan Manajemen Keuangan Daerah, Penerbit Andi, Yogyakarta.

Miyasto, 1991. Pajak Penjualan dan Pajak Pertambahan Nilai. Studi Mengenai Dampak Terhadap Harga, Penerimaan dan Struktur, Yogyakarta: Universitas Gajah Mada.

Kaho, Josep Riwu. 1997. Prospek Otonomi Daerah di Negara Republik Indonesia, Raja Grafindo Persada, Jakarta

Koswara, E. 2000. Menyongsong Pelaksanaan Otonomi Daerah Berdasarkan Undang UndangNo.22 Tahun 1999 : suatu telaahan dan Menyangkut Kebijakan Pelaksanaan dan Kompleksitasnya, CSIS xxix no.1: 51-52.

Mangkoesoebroto, Guritno. 1993. Ekonomi Publik, BPFE, Jogyakarta.

Mardiasmo, 2003. Perpajakan, Yogyakarta : Penerbit Andi

Mardiasmo dan Akhmad Makhfatih. 2000. Perhitungan Potensi Pajak dan retribusi daerah di Kabupaten Magelang : Laporan Penelitian, PAU Studi Ekonomi UGM, Yogyakarta.

Nurcolis, Hanif. 2007. Teori dan Praktik Pemerintahan dan Otonomi Daerah, Jakarta : PT Grasindo.

Rahayu, Betty. 2011. Analisis Potensi Pajak Hotel terhadap Realisasi Penerimaan Pajak Hotel Di Kabupaten Gunungkidul, Skripsi : Universitas Diponegoro.

Ratu, Andi. Nurdi Brasit dan Jusni. 2010. Strategi Peningkatan Kontribusi Usaha Pertambangan terhadap Pendapatan Asli Daerah (PAD) Kota Palopo, Jurnal (Online), (pascaunhas.ac.id/jurnal/), diakses 11 Februari 2016.

Riyardi, Agung, Dkk. 2000. Studi Potensi PADS Kabupaten Sukoharjo: Laporan Penelitian kerja sama FE-UMS dan DPRD Kabupaten Sukoharjo. 
Sidik, M. 1999. Perimbangan Keuangan antara Pemerintah Pusat dan Daerah serta Implikasinya Terhadap Pembiayaan Otonomi Daerah: Laporan Khusus, Yayasan Indonesia Forum, Jakarta.

Soeparno. 1993. Intensifikasi dan Ekstensifikasi Potensi sumber Pendapatan Daerah Dalam Pemberdayaan Otonomi Daerah di Kabupaten Sukoharjo, Badan Litbang Depdagri, Jakarta.

Saray, Ninda. 2012. Pajak Pengambilan Bahan Galian Golongan C dan Kontribusinya terhadap Pendapatan Asli (PAD) Daerah di Kabupaten Lumajang, Skripsi : Universitas Negeri Surabaya.

Sondang P. Siagian. 2001. Manajemen Sumber Daya Manusia, Jakarta: Bumi Aksara.

Sugianto. 2007. Pengelolaan Pemerintah Daerah dalam Aspek Keuangan, Pajak, dan Retribusi Daerah, Jakarta : Cikal Sakti.

Suwarno, Agus Endro. 2008. Efektifitas Evaluasi Potensi Pajak Daerah sebagai Sumber Pendapatan Asli Daerah, Jurnal : Akuntansi dan Keuangan Volume Nomor 2, September 2008, hlm. 162-173 (online), (publikasiilmiah.ums.ac.id), diakses 14 Januari 2016.

Triantoro, Arvian. 2010. Efektifitas Pemungutan Pajak Reklame dan Kontribusinya terhadap Penerimaan Pajak Daerah di Kota Bandung, Fokus Ekonomi, (online), Vol. 5 No. 1 Juni $2010: 1$ - 24, (http://www.e- bookspdf.org), diakses 28 Januari 2016.

Undang-Undang RI Nomor 34 Tahun 2000, Tentang Perubahan atas UndangUndang RI Nomor 18 Tahun 1997 Tentang Pajak dan Daerah dan Retribusi Daerah.

Undang-Undang RI Nomor 28 Tahun 2009, Tentang Pajak Daerah dan Retribusi Daerah. 